\title{
The status of the avifauna of Loru Protected Area, Santo, Vanuatu
}

\author{
JENNIFER BOWEN
}

\section{Summary}

Loru Protected Area covers 220 ha and is situated on the east coast of Espiritu Santo, the largest island in the archipelago of Vanuatu. Despite its small size, 23 of the 64 breeding land and freshwater birds of Vanuatu were sighted in Loru and 10 of the 23 restricted-range species, including two Vulnerable, one Near-threatened and five species endemic to the archipelago. Transects were used to estimate the densities of populations which were either easy to see or had distinctive calls. Variable circular plots were also used to estimate density and to examine the relationship between bird populations and habitat. Plots were allocated to one of two categories, undisturbed, mature lowland forest or disturbed, secondary growth forest. Populations of three species differed significantly between the two habitats: Red Jungle Fowl Gallus gallus, Golden Whistler Pachycephala pectoralis and Vanuatu Flycatcher Neolalage banksiana. All had higher densities in undisturbed forest. More protected areas need to be established on Santo and other islands in the archipelago to ensure the future survival of the Vanuatu avifauna.

Loru Protected Area s'étend sur 220 hectares sur la côte est d'Esprirtu Santo, la plus grande île de l'archipel de Vanuatu. Malgré sa petite taille, 23 des 64 oiseaux de terre et d'eau douce de Vanuatu ont été observés à Loru lors de la reproduction, ainsi que 10 des 23 espèces peu nombreuses, dont deux sont "Vulnerable", une est "Near-threatened" et cinq sont endémiques à l'archipel. Des lignes imaginaires furent tracées pour estimer les densités de populations qui étaient faciles à voir ou qui avaient un cri distinctif. Différentes parcelles de terre circulaires furent aussi utilisées pour estimer la densité et examiner les relations entre les oiseaux et leur habitat. Les parcelles furent allouées à l'une des deux catégories suivantes, soit à la forêt de plaine intacte et adulte, soit à la forêt issue d'une deuxième pousse. Selon l'habitat, le nombre d'oiseaux recensé appartenant aux trois espèces: Coq Bankiva Gallus gallus, Siffleur d'Or Pachycephala pectoralis et Gobe-mouches de Vanuatu Neolalage banksiana, fut très différent. Toutes avaient une densité plus importante dans la forêt intacte. Il est nécessaire d'établir de plus grandes réserves sur l'île de Santo ainsi que sur d'autre îles de l'archipel afin d'assurer la survie des oiseaux de Vanuatu.

Loru Protected Area i kavremap 220 ha mo i stap klosap long solwota long is Santo, wan aelan we i moa big long ol narafala aelan blong Vanuatu. Loru i smol be hemi gat 23 blong 64 kin pijin we i stap long Vanuatu ol yea nomo, mo 10 blong 23 kin pijin blong Vanuatu we i gat plente long narafala kontri tu. Long ol pijin ia, tu kin i "Vulnerable" (numba blong hem i stap ko doan kwiktaem), wan i "Near-threatened" (i stap klosap long "Vulnerable") mo faef i stap long Vanuatu nomo. Long ol pijin we i esi long lukluk o i singaot strong, i makem wan spesel sove blong rod blong bus long faenemaot hamas pijin i stap long wan eria. I stap makem wan narafala kin sove tu we man i stap kwaet 


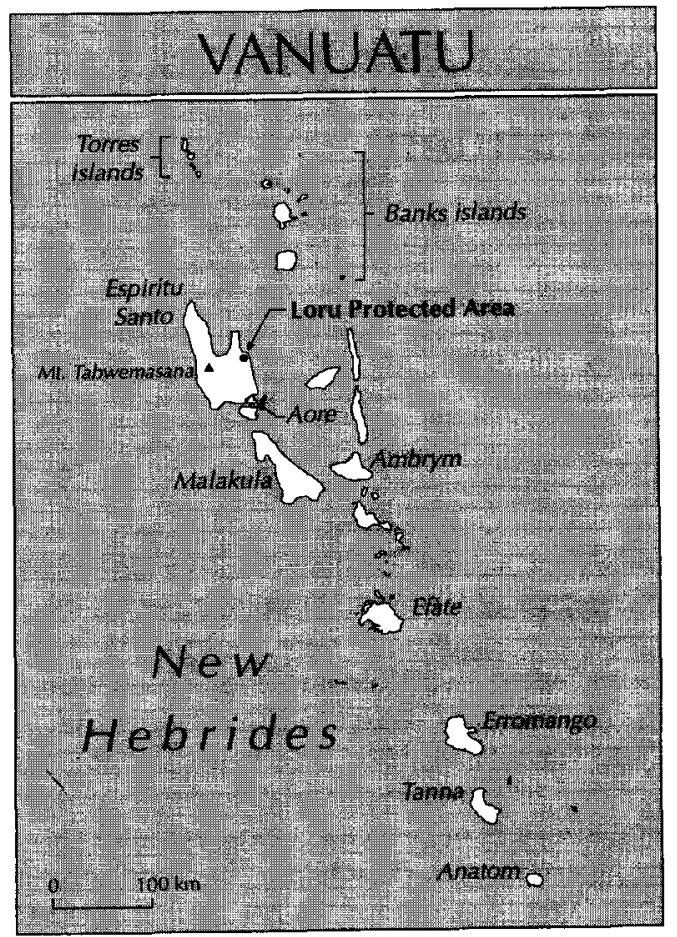

Figure 1. Map of Vanuatu with Loru Protected Area.

long plente difren ples long faenemaot hamas pijin i stap mo wanem kin bus i likem. Evri ples we man i stap kwaet long sove ia, i givem spesel nem long wanem kin bus i stap: wan kin we ol bigfala wud i stap mo wan kin we man o hurican i spolem. I gat tri pijin wea ol i difren tumas long tu kin bus ia: Wael Faol Gallus gallus, Nosor (es Santo langwis) Pachycephala pectoralis mo Kowboe Pijin Neolalage banksiana. Long pijin ia i gat moa long kin bus we bigfala wud i stap. I nidim plente moa protected area long Santo mo ol narafala aelan blong Vanuatu sipos i no wantem lusen samfala pijin blong Vanuatu long fiuja.

\section{Introduction}

\section{Vanuatu}

Vanuatu (formerly the New Hebrides) is an archipelago in the south-west Pacific consisting of over 200 islands stretching over $1,100 \mathrm{~km}$. The main group of islands form a " $Y$ " shape with the western arm reaching $13^{\circ} \mathrm{S}$ at the Banks and Torres islands, and the southern part of the " $\mathrm{Y}$ " at the islands of Matthew and Hunter at $22^{\circ} \mathrm{S}$ (Figure 1). The archipelago embraces volcanically active islands, small coral atolls and large islands with towns, mountains and freshwater lakes. Vanuatu occupies $11,880 \mathrm{~km}^{2}$, the largest island being Espiritu Santo $\left(3,900 \mathrm{~km}^{2}\right)$. The climate is tropical with annual temperatures ranging from 21 to $28^{\circ} \mathrm{C}$ and rainfall from 1,500 to 4,200 $\mathrm{mm}$ (Diamond and Marshall 1976a). The rainy season occurs from November to April during which the islands are prone to cyclones. 
The majority of vegetation in Vanuatu is tropical rainforest although there are other biomes including grasslands, mangrove forests and montane rainforests (Bregulla 1992).

\section{The avifauna of Vanuatu}

Vanuatu, together with the Santa Cruz islands to the north (politically part of the Solomon islands), has been identified as one of some 220 Endemic Bird Areas (EBAs) around the world (ICBP 1992). A total of 121 bird species have been recorded in Vanuatu of which 64 breed on land or freshwater. There are 23 restricted-range species in Vanuatu, six of which are classified as globally threatened (status Vulnerable), four are Near Threatened and eight are endemic to the archipelago (Collar et al. 1994).

\section{Loru Protected Area}

Loru Protected Area was established on 26 April 1995 and is situated on the east coast of Santo, covering 220 ha (Figure 1). Although there are general reports on the fauna and flora of Santo there is no detailed information from Loru or the surrounding area, emphasizing the importance of accumulating knowledge on the region.

Loru has a diverse vegetation which can be attributed to two main factors. First, over the past years cyclone damage has caused patches of undisturbed, mature lowland forest to become integrated with disturbed, secondary growth forest. Second, a cliff divides a coastal plateau from a ridge, causing variation in vegetation over an altitudinal range of $120 \mathrm{~m}$ from coastal species to lowland forest species. Associated species such as Java cedar Bischofia javanica, wild nutmeg Myristica fatua and milk tree Antiaris toxicaria are found on top of the ridge along with Bambusa sp. stands, cottonwood Hibiscus tiliaceus thickets, primary forest species such as the bean tree Castanospermum australe and a large banyan, Ficus prolixa. The coastal species include gaiac Acacia spirorbis, ironwood Casuarina equisetifolia and Ficus littoralis. Lianas, epiphytes, tree ferns and fungi are found throughout Loru.

Aim

The aims of this project were twofold: to determine the population status of the restricted-range avifauna and to examine the relationship between bird populations and their habitat.

\section{Methods}

The study was undertaken between January and April 1995. Despite this being the cyclone season, there were few days with adverse environmental conditions sufficient to prevent data collection. Resident bird species were identified by visiting key points, such as fruiting and flowering trees, where high densities of birds might be expected. Special attention was paid to those species with restricted ranges. 


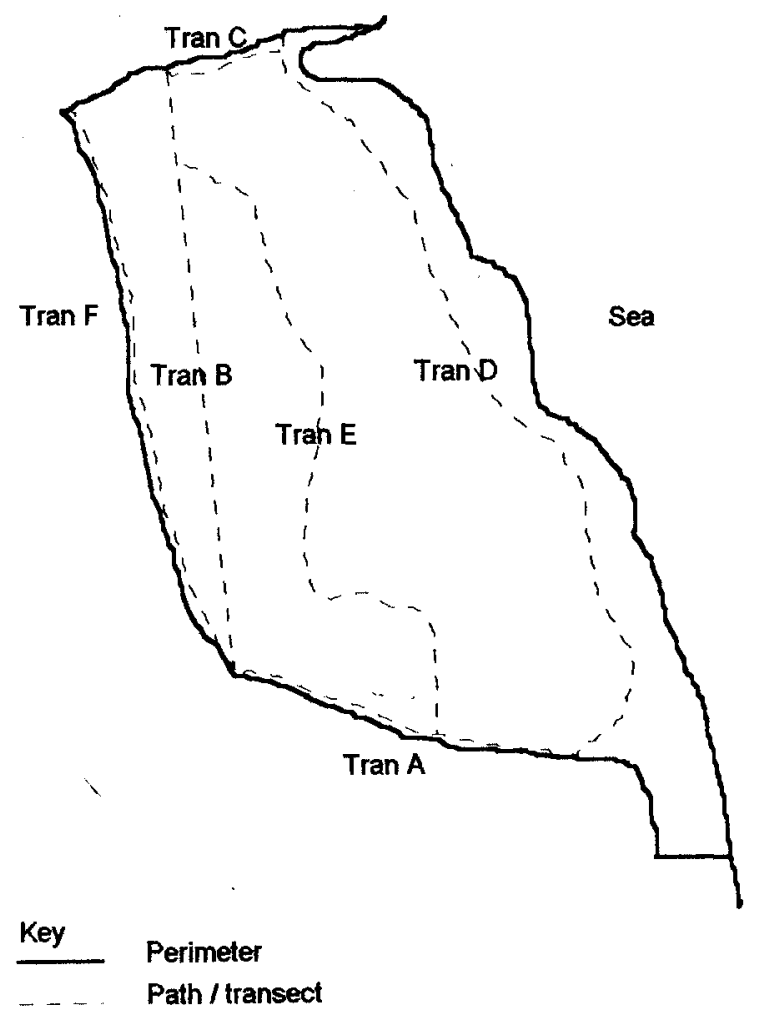

Figure 2. Transects in Loru Protected Area.

Six transects were each walked for five consecutive days. Two were paths used by locals, the remaining four were cut through the bush during the demarcation of the reserve (Figure 2).

\section{Transect description}
A $(825 \mathrm{~m})$
Newly cut along the perimeter of the reserve, through undisturbed, mature lowland forest and some disturbed, secondary growth forest
B $(984 \mathrm{~m}) \quad$ Newly cut within the reserve, through undisturbed, mature lowland forest and disturbed, secondary growth forest
C $(178 \mathrm{~m}) \quad$ Newly cut along the perimeter of the reserve through disturbed, secondary growth forest
D $(1,338 \mathrm{~m})$ Established path mainly through undisturbed, mature lowland forest
E $\quad(806 \mathrm{~m}) \quad$ Established path through undisturbed, mature lowland forest
F $(925 \mathrm{~m}) \quad$ Newly cut along the perimeter of the reserve, passing through undisturbed, mature lowland forest and disturbed, secondary growth forest

Belt transects were used for restricted-range species which were either easy to 


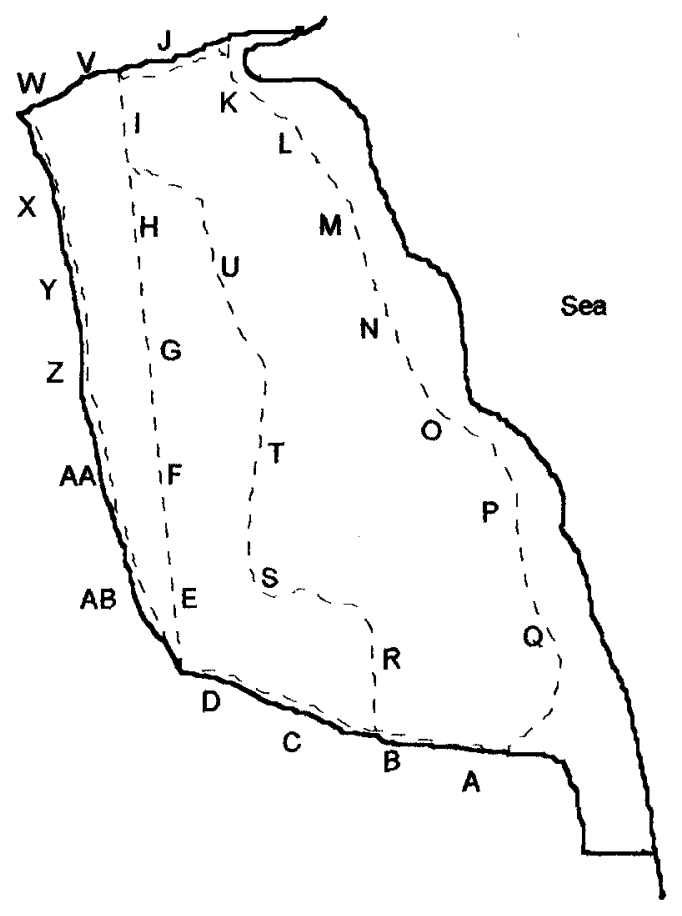

Figure 3. Variable circular plots in Loru Protected Area.

see or had distinctive calls. For the former, transects $20 \mathrm{~m}$ wide were used, the distance at which I could be sure that 100\% of birds would be detected. The perpendicular distance of each bird from the transect was measured.

Some birds had distinctive calls but could not be seen, so accurate measurement of distance could not be made. For these, the perpendicular distance from the observer were noted in equidistant bands using the loudness of the call as a distance value, this value being species dependent. These bands were calculated by locating a specific calling bird and measuring the distance it could be heard. This distance was divided into 11 equal bands, numbered from o to 10 , with 10 being the value when the bird could be heard directly overhead.

Variable circular plots (VCPs) were used to examine the relationship between bird populations and vegetation. There were 28 plots, $A-A B$, taken at 200-m intervals along the six transects (Figure 3). Recording began 1 minute after reaching the point to allow the birds to become accustomed to the observer. By plotting the number of species over time it was found that a 6-minute interval was long enough to hear all the birds in the plot but short enough for birds not to enter or exit the area and so distort the results. The distance of the bird from the observer was estimated up to $100 \mathrm{~m}$. Each plot was visited twice. Birds which flew above the canopy were noted separately.

Birds with a distinctive call, but in low numbers were plotted onto a map of the area; clusters were interpreted as territories to calculate a population density. Further information was gathered from local residents. 
Table 1. Avifauna of Loru Protected Area

\begin{tabular}{|c|c|c|}
\hline Species & English name & Status \\
\hline Ardea sacra & Eastern Reef Heron & \\
\hline Circus approximans approximans & Swamp Harrier & \\
\hline Falco peregrinus & Peregrine Falcon & App I, O \\
\hline Megapodius layardi & Vanuatu Megapode & $\mathrm{rr}, \mathrm{V}, \mathrm{e}$ \\
\hline Gallus gallus & Red Jungle Fowl & I \\
\hline Gallirallus philippensis & Buff-banded [Banded] Rail & $\mathrm{O}$ \\
\hline Ptilinopus greyii & Red-bellied Fruit Dove & $\mathrm{rr}$ \\
\hline Ptilinopus tannensis & Vanuatu [Yellow-headed] Fruit Dove & $\mathrm{rr}, \mathrm{NT}, \mathrm{e}$ \\
\hline Ducula pacifica pacifica & Pacific Imperial Pigeon & \\
\hline Columba vitiense leopoldii & White-throated Pigeon & \\
\hline Macropygia mackinlayi mackinlayi & Rufous-brown Pheasant-dove & \\
\hline Chalcophaps indica sandwichensis & Green-winged Ground [Emerald] Dove & \\
\hline Trichoglossus haematodus massena & Rainbow Lorikeet & App II \\
\hline Tyto alba & Barn Owl & App II, O \\
\hline Collocalia esculenta uropygialis & White-bellied [Glossy] Swiftlet & \\
\hline Halcyon chloris & White-collared Kingfisher & \\
\hline Halcyon farquhari & Chestnut-bellied Kingfisher & $\mathrm{rr}, \mathrm{V}, \mathrm{e}$ \\
\hline Coracina caledonica & Melanesian Cuckoo-shrike & $\mathrm{rr}$ \\
\hline Pachycephaloides pectoralis & Golden Whistler & \\
\hline Clytorhynchus pachycephaloides grisescens & Southern Shrikebill & $\mathrm{rr}$ \\
\hline Myiagra caledonica & Broad-billed Flycatcher & $\mathrm{rr}$ \\
\hline Neolalage banksiana & Vanuatu [Buff-bellied] Flycatcher & $\mathrm{rr}, \mathrm{e}$ \\
\hline Rhipidura fuliginosa & Grey [Collared] Fantai] & $\mathrm{O}$ \\
\hline Rhipidura spilodera spilodera & Spotted Fantail & $\mathrm{rr}$ \\
\hline Zosterops flavifrons & Vanuatu [Yellow] White-eye & $\mathrm{rr}, \mathrm{e}$ \\
\hline Zosterops lateralis & Grey-backed White-eye & \\
\hline Lonchura malacca & Black-headed Mannikin & $\mathrm{O}$ \\
\hline Acridotheres trisitis & Indian Mynah & $\mathrm{I}, \mathrm{O}$ \\
\hline Artamus leucorhynchus tenuis & White-breasted Woodswallow & \\
\hline
\end{tabular}

Key: V, Vulnerable; NT, Near-threatened; rr, restricted range; e, endemic; App 1, Appendix 1 CITES; App 2, Appendix 2 CITES; I, introduced species; O, Avifauna seen immediately outside Loru. Taxonomy taken from Bregulla (1992) with the exception of Megapodius layardi which is from Dekker and McGowan (1992).

\section{Results}

In Loru 23 species were identified, with a further six species immediately outside the reserve (Table 1 ). Ten of these were restricted-range species including two Vulnerable, one Near-threatened and five species endemic to the archipelago (Collar et al. 1994).

Population densities were estimated from transects and variable circular plot data using the program DISTANCE (Laake et al. 1993). Density estimations for six populations could be made from the transect data (Table 2). The Vanuatu Flycatcher, Spotted Fantail and Vanuatu White-eye have higher densities than Vanuatu Megapode, Vanuatu Fruit Dove and Vanuatu Kingfisher. Within the transects the densities for all six species are higher on transects D, E and F. This is possibly due to more undisturbed, mature lowland forest on the transects. The high number of Vanuatu Megapode and Vanuatu White-eye from transect C could be attributed to sightings directly on the transect leading to higher than expected densities. 
Table 2. Densities (calling birds per hectare with $95 \%$ confidence intervals in parentheses) determined on six transects in Loru Protected Area, Vanuatu

\begin{tabular}{|c|c|c|c|c|c|c|}
\hline Transect & $\begin{array}{l}\text { Vanuatu } \\
\text { Flycatcher }\end{array}$ & $\begin{array}{c}\text { Spotted } \\
\text { Fantail }\end{array}$ & $\begin{array}{l}\text { Vanuatu } \\
\text { White-eye }\end{array}$ & $\begin{array}{l}\text { Vanuatu } \\
\text { Megapode }\end{array}$ & $\begin{array}{c}\text { Vanuatu Fruit } \\
\text { Dove }\end{array}$ & $\begin{array}{l}\text { Vanuatu } \\
\text { Kingfisher }\end{array}$ \\
\hline A & $\begin{array}{c}1.86 \\
(1.05-3.31)\end{array}$ & $\begin{array}{c}2.75 \\
\left(1.7^{8}-4.26\right)\end{array}$ & $\begin{array}{c}3.53 \\
(2.22-5.62)\end{array}$ & $\begin{array}{c}0.01 \\
(0.00-0.07)\end{array}$ & $\begin{array}{c}0.24 \\
(0.17-0.34)\end{array}$ & $\begin{array}{c}0.08 \\
(0.03-0.21)\end{array}$ \\
\hline B & $\begin{array}{c}2.52 \\
(1.57-4.05)\end{array}$ & $\begin{array}{c}2.97 \\
(2.01-4.38)\end{array}$ & $\begin{array}{c}1.60 \\
(0.89-2.88)\end{array}$ & $\begin{array}{c}0.13 \\
(0.07-0.24)\end{array}$ & $\begin{array}{c}0.19 \\
(0.13-0.27)\end{array}$ & $\begin{array}{c}0.04 \\
(0.01-0.13)\end{array}$ \\
\hline $\mathrm{C}$ & $\begin{array}{c}1.33 \\
\left(0.3^{8-4.68)}\right.\end{array}$ & $\begin{array}{c}1.22 \\
\left(0.35^{-4.25}\right)\end{array}$ & $\begin{array}{c}6.81 \\
\left(3.5^{6-13.05}\right)\end{array}$ & $\begin{array}{c}0.3^{8} \\
(0.17 \multimap 0.87)\end{array}$ & 0 & $o$ \\
\hline D & $\begin{array}{c}3.70 \\
(2.55-5.38)\end{array}$ & $\begin{array}{c}5.66 \\
(4 \cdot 38-7 \cdot 32)\end{array}$ & $\begin{array}{c}3.90 \\
(2.65-5.73)\end{array}$ & $\begin{array}{c}0.21 \\
(0.13-0.34)\end{array}$ & $\begin{array}{c}0.05 \\
(0.03-0.10)\end{array}$ & $\begin{array}{c}0.24 \\
(0.15-0.39)\end{array}$ \\
\hline $\mathrm{E}$ & $\begin{array}{c}3.07 \\
(1.91-4.95)\end{array}$ & $\begin{array}{c}8.86 \\
(6.81-11.53)\end{array}$ & $\begin{array}{c}3.61 \\
(2.27-5 \cdot 75)\end{array}$ & $\begin{array}{c}0.08 \\
(0.04-0.19)\end{array}$ & $\begin{array}{c}0.23 \\
(0.16-0.33)\end{array}$ & $\begin{array}{c}0.16 \\
(0.08-0.31)\end{array}$ \\
\hline $\mathrm{F}$ & $\begin{array}{c}3.29 \\
(2.13-5.08)\end{array}$ & $\begin{array}{c}2.46 \\
(1.60-3.77)\end{array}$ & $\begin{array}{c}6.52 \\
\left(4.5^{2}-9.39\right)\end{array}$ & $\begin{array}{c}0.04 \\
(0.01-0.11)\end{array}$ & $\begin{array}{c}0.07 \\
(0.04-0.12)\end{array}$ & $\begin{array}{c}0.14 \\
(0.07 \multimap 0.28)\end{array}$ \\
\hline Average & $\begin{array}{c}2.92 \\
(2.11-4.03)\end{array}$ & $\begin{array}{c}4.41 \\
(2.45-7.93)\end{array}$ & $\begin{array}{c}3.95 \\
(2.43-6.43)\end{array}$ & $\begin{array}{c}0.12 \\
(0.05-0.27)\end{array}$ & $\begin{array}{c}0.14 \\
(0.07-0.27)\end{array}$ & $\begin{array}{c}0.14 \\
(0.07-0.26)\end{array}$ \\
\hline
\end{tabular}

The relationship between species of bird and habitat was examined using variable circular plots. Thirteen species, which had been heard more than three times, were included in the analysis (Table 3). Differences between mean populations within forest types were examined using the $z$-test (Table 4).

For the comparison, the three main mature or climax canopy species, for lowland forest areas, were grouped together in one category. These were the milk tree, dragon plum Dracontomelon vitiense and New Guinea rosewood Pterocarpus indicus. The total percentage cover of these three species at the centre of each VCP was calculated and totals which exceeded 50\% were grouped into Category I (undisturbed, mature lowland forest). The remaining VCPs were allocated to Category 2 (disturbed, secondary growth forest).

Table 3. Estimates of population size of calling birds in Loru Protected Area

\begin{tabular}{lccr}
\hline Species & \multicolumn{2}{c}{ VCPs } \\
\cline { 2 - 4 } & $\begin{array}{l}\text { Undisturbed forest } \\
(150 \mathrm{ha})\end{array}$ & $\begin{array}{c}\text { Disturbed forest } \\
(50 \mathrm{ha})\end{array}$ & $\begin{array}{c}\text { Total } \\
(200 \mathrm{ha})\end{array}$ \\
\hline Vanuatu Megapode & $\mathbf{1 4}$ & 4 & 18 \\
Red Jungle Fowl & 30 & 0 & $30^{\text {a }}$ \\
Vanuatu Fruit Dove & 68 & $\mathbf{1 1}$ & 79 \\
Pacific Imperial Pigeon & $\mathbf{1 , 2 3 0}$ & 423 & $\mathbf{1 , 6 5 3}$ \\
Rainbow Lorikeet & 2,217 & 0 & 2,217 \\
White-collared Kingfisher & 26 & 0 & 26 \\
Chestnut-bellied Kingfisher & 11 & 9 & 20 \\
Melanesian Cuckoo-shrike & 33 & 20 & 53 \\
Golden Whistler & 599 & 0 & 599 \\
Southern Shrikebill & 120 & 0 & 120 \\
Vanuatu Flycatcher & 990 & 37 & $\mathbf{1 , 0 2 7}$ \\
Spotted Fantail & 443 & 101 & 544 \\
Vanuatu White-eye & 2,903 & 767 & 3,670 \\
\hline
\end{tabular}

N.B. Coastal area (2o ha) excluded.

a Calling males only. 
Table 4. Population density (calling birds per hectare with $95 \%$ confidence intervals in parentheses) in undisturbed (Category 1 ) and disturbed (Category 2 ) vegetation estimated from variable circular plots $(n=28)$ in Loru Protected Area

\begin{tabular}{llll}
\hline Species & Undisturbed $(n=21)$ & Disturbed forest $(n=7)$ & $z$ \\
\hline Vanuatu Megapode & $0.09(0.04-0.23)$ & $0.08(0.03-0.25)$ & 0.16 \\
Red Jungle Fowl & $0.20(0.08-0.51)$ & 0 & $2.0^{*}$ \\
Vanuatu Fruit Dove & $0.45(0.23-0.85)$ & $0.21(0.05-0.88)$ & 1.17 \\
Pacific Imperial Pigeon & $8.20(3.00-22.38)$ & $8.46(2.99-23.96)$ & 0.04 \\
Rainbow Lorikeet & $14.78(0.06-3903.6)$ & 0 & 0.08 \\
White-collared Kingfisher & $0.17(0.05-0.63)$ & 0 & 1.42 \\
Chestnut-bellied Kingfisher & $0.07(0.03-0.15)$ & $0.17(0.03-0.78)$ & 0.81 \\
Melanesian Cuckoo-shrike & $0.22(0.06-0.86)$ & $0.39(0.08-1.91)$ & 0.49 \\
Golden Whistler & $3.99(2.31-6.89)$ & 0 & $3.95^{*}$ \\
Southern Shrikebill & $0.80(0.14-4.63)$ & 0 & 1.21 \\
Vanuatu Flycatcher & $6.60(3.50-12.46)$ & $0.73(0.09-5.72)$ & $2.62^{*}$ \\
Spotted Fantail & $2.95(1.97-4.42)$ & $2.02(0.78-5.21)$ & 0.93 \\
Vanuatu White-eye & $19.35(7.84-47.76)$ & $15.34(4.66-50.51)$ & 0.31 \\
\hline
\end{tabular}

* Significantly different $(P<0.05)$. All other comparisons are non-significant.

The majority of VCPs fell into Category 1 while VCPs C, G, I, J, K, R and Y were in Category 2. The density of birds in the two forest categories are given in Table 3. There was a significant difference in density of three species: Red Jungle Fowl, Golden Whistler and Vanuatu Flycatcher. All were more numerous in the undisturbed forests. It was estimated from the vegetation in the variable circular plots that $75 \%$ of Loru comprised undisturbed, mature lowland forest and $25 \%$ disturbed, secondary growth forest, a total of 200 ha of Loru; the remaining 20 ha were inaccessible.

Three scarce species with distinctive calls were Melanesian Cuckoo-shrike, Southern Shrikebill and Broad-billed Flycatcher. Melanesian Cuckoo-shrike was heard 26 times, Southern Shrikebill heard 21 times and Broad-billed Flycatcher was seen six times whilst walking the transects. Territory clusters were formulated using Common Birds Census methods (Bibby et al. 1992). There were six territories of Melanesian Cuckoo-shrike and five of Southern Shrike-bill on the transects, with possibly five territories of Broad-billed Flycatcher.

\section{Restricted-range species}

Below is a summary of the 10 restricted-range species (Bregulla 1992), which were studied in Loru.

\section{Vanuatu Megapode Megapodius layardi}

Status: a threatened, restricted-range species endemic to the archipelago (Collar et al. 1994).

Distribution: found only in Vanuatu, occurring on most of the central and northern islands, mainly in lowland forests although it is known to reach moderate altitudes (Bregulla 1992). 
Threats: the eggs are collected for food from accessible nesting grounds (Bowen 1996). Agriculture and development of the land has encroached into the nesting grounds resulting in a population decline.

Protection: partly protected. Hunting is not permitted under Vanauatu law between 1 July and 31 March (Bregulla 1992), although this is generally not respected.

Sightings: seen on many occasions in the forest and were very vocal in the morning. In March, on two separate occasions, two birds were seen chasing each other, the chaser having its wings held low on the ground. The Vanuatu Megapode uses the microbial decomposition of roots to provide the heat to incubate the eggs and in Loru one nest was found between the buttress roots of D. vitiense.

Population size: estimated population in Loru was 24 individuals using transects, or 18 individuals using VCPs.

\section{Red-bellied Fruit Dove Ptilinopus greyii}

Status: a restricted-range species (Collar et al. 1994).

Distribution: widespread in the south-west Pacific occurring in Micronesia, Polynesia, Fiji and Melanesia; the most common fruit dove in Vanuatu. It is found on many of the islands in Vanuatu including the smaller ones, and inhabits lowland areas and moderate altitudes. A forest bird, usually perching in the denser part of the canopy and remaining in the foliage.

Threats: depleting habitat.

Protection: partly protected. Hunting is not permitted under Vanauatu law between 1 July and 31 March (Bregulla 1992).

Sightings: although seen in the forest, albeit infrequently, it was never identified whilst singing and it called infrequently. In January one white egg was found in a nest in a plantation near Kole 1 village. The nest was constructed out of small twigs in a Mandarin tree and was approximately $3 \mathrm{~m}$ off the ground.

Population size: no estimation of population could be made due to sporadic calling of the species.

\section{Vanuatu (Yellow-headed) Fruit Dove Ptilinopus tannensis}

Status: a restricted-range species endemic to the archipelago (Collar et al. 1994). Distribution: widely distributed through the archipelago although there have been no records from the Torres group, Ureparapara, Makura, Aniwa and Futana (Bregulla 1992). Common in lowland areas and moderate altitudes but not found at high altitudes. It is found in or near fruiting trees which are usually in true forests although it is also found in open areas which have fruiting trees nearby. Threats: depleting habitat.

Protection: partly protected. Hunting is not permitted under Vanuatu law between 1 July and 31 March. Could soon become endangered if no further conservation measures are introduced (Bregulla 1992).

Sightings: seen on one occasion and not whilst singing. It is common in the far eastern part of Loru. 
Population size: estimated population in Loru was 28 individuals using transects, or 79 individuals using VCPs.

\section{Vanuatu (Chestnut-bellied) Kingfisher Halcyon farquhari}

Status: a threatened, restricted-range species endemic to the archipelago (Collar et al. 1994).

Distribution: found only in the northern islands of Santo, Malo and Malekula, Santo having the main population. Not as common as the White-collared Kingfisher and found in more forested areas than this species (Bregulla 1992).

Threats: depleting habitat.

Protection: fully protected by law (Bregulla 1992).

Sightings: the call is a monotonous single note, heard throughout the day but less frequently in the early morning. The bird is often quiet on approaching and relies on remaining very still to go undetected. When calling the body is held in an upright position and the bird remains still apart from the tail moving in time with the call. After singing in one direction the kingfisher will stop, move to a new position and then begin singing again. The bird will sing for a long time in one position, usually in a relatively open or prominent place, such as high up in the canopy, where it can get a good view of its territory. From December to March the kingfishers seen had very pronounced red chests. In December one kingfisher was seen being bombarded by the Vanuatu Flycatcher and on 23 February 1995 one was seen with a worm in its mouth.

Population size: estimated population in Loru was 28 individuals using transects, or 20 individuals using VCPs.

\section{Melanesian Cuckoo-shrike Coracina caledonica}

Status: a restricted-range species (Collar et al. 1994).

Distribution: found only in the south-west Pacific and on the islands of New Caledonia, Loyalty Islands, Solomons and Vanuatu. It is a common species and in Vanuatu it is found on Santo, Malo, Malekula and Erromango (Bregulla 1992). It inhabits forests and open areas and is found in all altitudes although it prefers lowland.

Threats: depleting habitat.

Protection: none.

Sightings: seen occasionally in Loru in the lower understorey and its piercing call could be heard in the canopy.

Population size: estimated population in Loru was 53 individuals using VCPs.

\section{Southern Shrikebill Clytorhynchus pachycephaloides}

Status: a restricted-range species (Collar et al. 1994).

Distribution: found only in New Caledonia and Vanuatu, where it occurs on Erromango and the northern islands (Bregulla 1992), being more common in the north. Mainly inhabits dense forest, although found on the coast on Santo.

Threats: as forest clearance continues it is found at higher altitudes where denser forests occur and on some islands it is restricted to the highlands. 
Protection: none.

Sightings: often heard in the understorey and occasionally seen.

Population size: estimated population in Loru was 120 individuals using VCPs.

\section{Broad-billed Flycatcher Myiagra caledonica}

Status: a restricted-range species (Collar et al. 1994).

Distribution: found on Rennell Island in the Solomons, Loyalty Islands and New Caledonia (Bregulla 1992). Common in Vanuatu although there have been no records from Paama and Tongaiki (Bregulla 1992). Found near the coast more than in the mountains and in disturbed areas, gardens and open areas under the canopy.

Threats: none.

Protection: none.

Sightings: two females were often seen in the camp area and feeding on the wing. They did not seem concerned with humans and perched close to the cooking areas. Only the female was seen in Loru.

Population size: estimated number of territories along the transects was five.

Vanuatu (Buff-bellied) Flycatcher Neolalage banksiana

Status: a restricted-range species and an endemic genus to the archipelago (Collar et al. 1994).

Distribution: found in central Vanuatu, on the larger islands, and on Vanua Lava in northern Vanuatu (Bregulla 1992), in open forests, sometimes in gardens, and usually seen in pairs.

Threats: none.

Protection: none.

Sightings: three nests were found in Loru ; the first was from the previous year, the second had a bird incubating eggs and the third contained two chicks. The nests were woven out of twigs and were built in shrubs in the darker parts of the forest. The third nest was observed over a period of 12 days, when only one chick flew on the 23-24 January 1995.

Population size: estimated population in Loru was 584 individuals using transects, or 1,027 individuals using VCPs.

\section{Spotted Fantail Rhipidura spilodera}

Status: a restricted-range species (Collar et al. 1994).

Distribution: three races, found in New Caledonia, Loyalty Islands, Fiji and Vanuatu (Bregulla 1992). Found in all types of wooded habitat in the lower under storey and more common in the mountains.

Threats: none.

Protection: none.

Sightings: two nests were seen in Loru. The first, built in $M$. fatua, was seen as two chicks were frightened out of it on 18 January 1995. The second nest had three eggs, cream in colour with brown dapples at the larger end. The eggs were 
being incubated in late January although fledglings were seen whilst walking during this time.

Population size: estimated population in Loru was 882 individuals using transects, or 544 individuals using VCPs.

\section{Vanuatu White-eye Zosterops flavifrons}

Status: a restricted-range species endemic to the archipelago (Collar et al. 1994). Distribution: the most common species in the archipelago and seen on all the islands except Ureparapara and Mota Lava (Bregulla 1992). There are seven races in Vanuatu and they differ by the amount of yellow in the plumage. They are coastal to mountain species.

Threats: none.

Protection: none.

Sightings: often seen in pairs or in small groups which were foraging in the lower or upper canopy.

Population size: estimated population in Loru was 790 individuals using transects, or 3,670 individuals using VCPs.

\section{Discussion}

Little is known of the status, behaviour and breeding strategies of the resident avifauna of Vanuatu, especially the restricted-range and endemic species. Information on these species is vital if effective conservation strategies are to be developed, especially those confined to the lowland forests which is diminishing due to the encroachment of gardens and coconut plantations, and by logging companies.

\section{Density estimates}

Density estimates were given for the number of birds calling, irrespective of sex, which usually could not be distinguished. The density estimates were therefore considered to relate with individuals, not breeding pairs. There were two exceptions: all Red Jungle Fowl calls were the male territorial call, similar to the domestic cockerel, and only the female Broad-billed Flycatcher was sighted.

Variable circular plots were allocated to a forest category by the canopy species at the plot centre. The Red Jungle Fowl, Golden Whistler and Vanuatu Flycatcher were the only species which exhibited significant differences in density between undisturbed, mature lowland forest and disturbed, secondary growth forest. All preferred the former habitat.

A distinct habitat division has been noted between the kingfishers, Vanuatu Kingfisher being confined to the forests and White-bellied Kingfisher inhabiting open areas (Diamond and Marshall 1976a). However, in Loru, White-bellied Kingfisher was seen in both open areas and forests, suggesting overlapping territories.

Vanuatu White-eye and Grey-backed White-eye (Silvereye) Zosterops lateralis, coexist in gardens and overgrown plantations on Efate (Medway and Marshall 
1975). In Loru, Vanuatu White-eye was only seen in the forest and Grey-backed White-eye only in the open coastal habitat.

\section{Conservation}

Fifty-five of the 64 native species of land and freshwater birds breeding on Vanuatu have been recorded on Espiritu Santo. Loru contains $42 \%$ of these breeding species on Santo, a surprisingly large number for such a small area of the island. Those not found in Loru include four Vulnerable species (Vanuatu Mountain Pigeon Ducula bakeri, Santa Cruz Ground-dove Gallicolumba sanctacrucis, Royal Parrotfinch Erythrura regia, Santo Mountain Starling Aplonis santovestris), three Near-threatened species (Green Palm Lorikeet Charmosyna palmarum, Thicket Warbler Cichlornis whitneyi, Rusty-winged Starling Aplonis zelandica) and three endemics (Vanuatu Mountain Pigeon, Vanuatu Mountain Honeyeater Phylidonyris notabilis, Santo Mountain Starling). All of these species, except Rusty-winged Starling, are confined to forest at higher altitudes. Additional conservation measures need to be applied to counter the loss of many important bird habitats if the survival of Vanuatu's avifauna in its entirety, is to be assured. The encouragement and support of (similar) community-based protected areas in different biomes on Santo, and other islands, should be considered a priority. Further studies are also needed.

\section{Acknowledgements}

I thank the people of Kole 1 village on the east coast of Santo, especially Chief Kaleb Ser and his family, for their help in the identification of the local birds and their information on the birds of Santo. Many thanks to Roy Hills and the other members of the Vanuatu Protected Areas Initiative for their support. I also thank British Airways Assisting Conservation, BirdLife International with their support through the Phyllis Barclay-Smith Conservation Fund, United Biscuits, Air Vanuatu, Vanair and Padget Trust. Special thanks to Alison Stattersfield for her continued support and comments on earlier drafts, Gary Allport for his advice on surveying techniques, Andrew Raynor for producing the map and Martin Winters for the French translation. Thank you to the other sponsors of the expedition who made the work possible.

\section{References}

Bibby, C. J., Burgess, N. D. and Hill, D. A. (1992) Bird census techniques. London: Academic Press.

Bowen, J. C. (1996) Notes on the Vanuatu Megapode Megapodius layardi on Ambrym, Vanuatu. Bird Conserv. Int. 6: 401-407

Bregulla, H. L. (1992) Birds of Vanuatu. Oswestry, U.K.: Antony Nelson.

Buckland, S. T., Anderson, D. R., Burnham, K. P. and Laake, J. L. (1993) Distance sampling: estimating abundance of biological populations. London: Chapman and Hall.

Collar, N. J., Crosby, M. C., and Stattersfield, A. J. (1994) Birds to watch 2: the world list of threatened birds. Cambridge, U.K.: BirdLife International (BirdLife Conservation Series 4).

Dekker, R. W. R. J. and McGowan, P. J. K. (1992) Megapodes: an action plan for their conservation 1995-1999. Gland, Switzerland: International Council for Conservation of Nature and Natural Resources. 
Diamond, J. M. and Marshall, A. G. (1976a) Origin of the New Hebridean avifauna. Emu 76: 187-200.

Diamond, J. M. and Marshall, A. G. (1976b) Niche shifts in New Hebridean birds. Emu 77: 67-72.

Diamond, J. M. and Marshall, A. G. (1977) Distributional ecology of New Hebridean birds: a species kaleidoscope. J. Anim. Ecol. 46: 703-727.

ICPB (1992) Putting biodiversity on the map: priority areas for global conservation. Cambridge, U.K.: International Council of Bird Preservation.

Laake, J. L., Buckland, S. T., Anderson, D. R. and Burnham, K. P.(1993) DISTANCE User's Guide V2.0. Fort Collins, CO : Colorado Cooperative Fish and Wildlife Research Unit, Colorado State University.

Lee, K. E. (1975) Introductory remarks. Phil. Trans. R. Soc. Lond. B. 272: 269-276.

Medway, Lord and Marshall, A. G. (1975) Terrestrial vertebrates of the New Hebrides: origin and distribution. Phil. Trans. R. Soc. Lond. B. 272: 423-465.

JENNIFER BOWEN

Fir Close, Tubney, Nr. Abingdon, Oxon. OX13 5QQ. U.K. 